\title{
IMMUNOPATHOGENETIC FEATURES OF MONONUCLEOSIS IN CHILDREN WITH VARIOUS MICROBIAL FLORA OF THE RHINOPHARYNX
}

\author{
${ }^{1}$ Ph.D. student Guz O. V., \\ ${ }^{I}$ Ph.D., doctor med. sci., prof. Kuznetsov S., \\ ${ }^{2}$ immunologist Malutenko $C$. \\ ${ }^{1}$ Ukraine, Kharkiv, Kharkiv National Medical University. \\ ${ }^{2}$ Ukraine, Kharkiv, medical center Evivva
}

DOI: https://doi.org/10.31435/rsglobal_ws/30112019/6771

\section{ARTICLE INFO}

Received: 27 September 2019

Accepted: 12 November 2019

Published: 30 November 2019

\section{KEYWORDS}

Children,

infectious mononucleosis,

Epstein-Barr virus,

microbial flora,

immunity.

ABSTRACT

One of the most common childhood diseases is infectious mononucleosis (IM), which Epstein-Barr virus (EBV) is a causative factor. According to WHO statistics, more than 5 million children die every year from the indicated infectious pathology and its consequences in the world. Streptococcus pyogenes, Streptococcus pneumoniae and other Streptococcus, Enterococcus, Lactobacillus Actinomices, Neisseria, Actinomyces, Clostridium, Pseudomonas, Staphylococus epidermidis, Staphylococus aureus are most often detected in the oral cavity and nasopharynx. In the available literature there are practically no works that would consider the effect of microbial flora of the mucous membrane of the rhinopharynx on the formation of the immune response of children with IM.
\end{abstract}

Citation: Guz O. V., Kuznetsov S., Malutenko C. (2019) Immunopathogenetic Features of Mononucleosis in Children with Various Microbial Flora of the Rhinopharynx. World Science. 11(51), Vol.2. doi: 10.31435/rsglobal_ws/30112019/6771

Copyright: (C) 2019 Guz O. V., Kuznetsov S., Malutenko C. This is an open-access article distributed under the terms of the Creative Commons Attribution License (CC BY). The use, distribution or reproduction in other forums is permitted, provided the original author(s) or licensor are credited and that the original publication in this journal is cited, in accordance with accepted academic practice. No use, distribution or reproduction is permitted which does not comply with these terms.

Introduction. The urgency of the problem of infectious mononucleosis (IM) is determined by the high level of infection of the pediatric population with the Epstein-Barr virus (EBV), the possibility of developing an unfavorable course of the disease and the formation, in some cases, prolonged immunosuppression with a deficiency of T and B-cell of immunity [2,4].

The specific tropism of the Epstein-Barr virus (EBV) to immunocompetent cells, systemic damage to internal organs, a wide range of clinical forms of the disease, as well as the absence of specific prophylaxis, is an argument for further study of this infection $[1,3]$.

Today, mononucleosis is considered as a disease of the immune system. The prolonged persistence of the virus in many tissues and organs leads to their structural changes that affect all parts of the immune system (cellular and humoral) [5].

Many scientists believe that in the formation of the clinical picture of mononucleosis and the immune response of patients, not only EBV, but also bacteria located near the site of its entrance gate (the mucous membrane of the nose and oropharynx) play an important role [6,7].

In the oral cavity and nasopharynx are most often found Staphylococus epidermidis, Staphylococus aureus, Streptococcus pneumoniae, Streptococcus pyogenes Enterococcus, Lactobacillus Actinomices, Peptostreptococcus, Neisseria, Actinomyces, Clostridium, Pseudomonas and other bacteria. Unlimited colonization by any kind of bacteria can lead to the development of infectious pathology [8].

There are practically no works in the available literature that would consider the effect of the microbial flora of the nasopharynx and oropharynx on the formation of the immune response of patients with mononucleosis. 
In our opinion, studies in this direction will clarify the pathogenetic mechanisms of the formation of the clinical picture of the disease, its course and outcome, which will determine further ways to improve the treatment of patients.

Materials and methods. Under the supervision were 93 children aged three to nine years, patients with mononucleosis of moderate severity who were treated at the Regional Children's Infectious Clinical Hospital in Kharkiv, Ukraine. The diagnosis of IM was verified on the basis of positive results for the search for disease markers by ELISA (anti-EBV IgM and IgG) and PCR (detection of EBV DNA in the blood). In 31 children (first group), Streptococcus pyogenes at concentrations of $10^{-5}$ and higher was isolated during bacteriological examination of the mucosa of the nasopharynx and oropharynx. 30 (second group) $-10^{-4}$ degrees or less. In 32 (the third group), Staphylococcus aureus, Spirochetae buccalis, E. Coli, other bacteria or combinations thereof were sown in smears from the mucous membrane of the nasoropharynx. The immune status of patients was assessed by indicators of levels of populations and subpopulations of peripheral blood lymphocytes, which were determined by indirect immunofluorescence using monoclonal antibodies to surface antigens of lymphocytes $\mathrm{CD}^{+}, \mathrm{CD}^{+}, \mathrm{CD} 8^{+}, \mathrm{CD} 22^{+}$. As well as the content in their blood of interleukins $1 \beta, 4, \mathrm{TNF} \alpha$. The studies were carried out in the acute period (2-3 days of illness) and in the period of early convalescence (8-13 days). As a comparison, we took the corresponding indicators of 30 healthy children of the same age and gender.

Static processing of the results was carried out using computer programs Excel and Statistica 6.0. The normal distribution of the observation groups was checked by the Shapiro-Wilk criterion. The reliability of the difference in values was revealed using Student's test and Fisher's method. Differences were considered significant at a significance level of $\mathrm{P}<0.05$.

Results and discussions. In the acute period of mononucleosis, all children show characteristic signs of activation of anti-infection protection mechanisms. The content of proinflammatory IL-1 $\beta$ in blood serum in the onset of the disease in patients of all groups was significantly higher than in healthy children $(\mathrm{P} 1<0.05)$.

The initial period of mononucleosis was accompanied by a significant increase in the blood level of patients with the level of TNF- $\alpha$ compared with its content in healthy children $(\mathrm{P} 1<0.05)$. The level of pro-inflammatory TNF- $\alpha$ in patients of the first group was significantly higher than similar indicators for children of the second and third groups $(\mathrm{P} 2,3<0.05)$.

Table 1. Indicators of the immune status of patients in the acute period and in the period of early reconvalescence of mononucleosis, $(\mathrm{M} \pm \mathrm{m})$

\begin{tabular}{|c|c|c|c|c|c|}
\hline \multirow{2}{*}{$\begin{array}{c}\text { Indicator } \\
\text { Interleukin: } \\
\mathrm{pg} / \mathrm{ml} \\
\mathrm{IL}-1 \beta\end{array}$} & Period & $\begin{array}{c}\text { First group } \\
(\mathrm{n}=31)\end{array}$ & $\begin{array}{c}\text { Second group } \\
(\mathrm{n}=30)\end{array}$ & $\begin{array}{c}\text { Third group } \\
(\mathrm{n}=32)\end{array}$ & $\begin{array}{c}\text { Reference } \\
\text { Values }\end{array}$ \\
\cline { 2 - 5 } & reconvalescence & $15.03 \pm 1.28^{1,2,3}$ & $8.9 \pm 0.94^{1,2}$ & $8.0 \pm 0.54^{1,3}$ & \multirow{2}{*}{$5.32 \pm 1.73$} \\
\hline \multirow{2}{*}{$\mathrm{IL}-4$} & acute period & $3.66 \pm 0.24^{2,3}$ & $5.40 \pm 0.30^{1,2}$ & $5.10 \pm 0.21^{1,3}$ & \multirow{2}{*}{$2.06 \pm 0.94$} \\
\cline { 2 - 5 } & reconvalescence & $4.60 \pm 0.85^{2,3}$ & $6.30 \pm 0.62^{1,2}$ & $6.30 \pm 0.48^{1,3}$ & \\
\hline \multirow{2}{*}{ TNF- $\alpha$} & acute period & $11.20 \pm 1.43^{1,2,3}$ & $6.90 \pm 1.12^{1,2}$ & $6.30 \pm 1.08^{1,3}$ & \multirow{2}{*}{$2.69 \pm 1.67$} \\
\cline { 2 - 5 } & reconvalescence & $7.9 \pm 0.42^{1,2,3}$ & $5.6 \pm 0.49^{1,2}$ & $5.6 \pm 0.29^{1,3}$ & \\
\hline \multirow{2}{*}{$\mathrm{CD} 3+, \%$} & acute period & $47.16 \pm 0.74^{1,2,3}$ & $57.30 \pm 0.52^{1,2}$ & $58.10 \pm 0.72^{1,3}$ & \multirow{2}{*}{$60.60 \pm 1.20$} \\
\cline { 2 - 5 } & reconvalescence & $51.03 \pm 0.70^{1,2,3}$ & $59.83 \pm 0.9^{1,2}$ & $60.46 \pm 0.2^{1,3}$ & \\
\hline \multirow{2}{*}{$\mathrm{CD} 4+, \%$} & acute period & $30.57 \pm 0.42^{1,2,3}$ & $33.86 \pm 0.34^{1,2}$ & $34.02 \pm 0.22^{1,3}$ & \multirow{2}{*}{$36.30 \pm 0.75$} \\
\cline { 2 - 5 } & reconvalescence & $31.83 \pm 0.38^{1,2,3}$ & $35.53 \pm 0.34^{1,2}$ & $35.53 \pm 0.12^{1,3}$ & \\
\hline \multirow{2}{*}{$\mathrm{CD} 8+, \%$} & acute period & $19.37 \pm 0.34^{1,2,3}$ & $23.40 \pm 0.39^{1,2}$ & $23.60 \pm 0.12^{1,3}$ & \multirow{2}{*}{$25.70 \pm 0.68$} \\
\cline { 2 - 5 } & reconvalescence & $21.07 \pm 0.46^{1,2,3}$ & $25.40 \pm 0.38^{1,2}$ & $25.40 \pm 0.04^{1,3}$ & \\
\hline \multirow{2}{*}{$\mathrm{CD} 22+, \%$} & acute period & $35.60 \pm 0.25^{1,2,3}$ & $32.56 \pm 0.42^{1,2}$ & $32.63 \pm 0.28^{1,3}$ & \multirow{2}{*}{$17.30 \pm 0.79$} \\
\cline { 2 - 5 } & reconvalescence & $33.97 \pm 0.35^{1,2,3}$ & $30.36 \pm 0.48^{1,2}$ & $28.08 \pm 0.78^{1,3}$ & \\
\hline
\end{tabular}


Note:

${ }^{\mathrm{P}} 1$ - reliability of the difference in the digital values of indicators of healthy and sick children;

P2 - probability of the characteristic of the first group relative to the second group;

${ }^{\mathrm{P}}$ - probability of the characteristic of the first group relative to the third group;

${ }^{\mathrm{P}} 4$ - probability sign between the second and third groups.

When studying the levels of IL-4 in the blood serum of children of the studied groups, an increase in its content was revealed in comparison with healthy children, however, a significant difference in its content was determined only in the indicators of children of the second, third and control groups $(\mathrm{P} 1<0.05)$. And although in patients of the first group there was an increase in the level of IL-4 in the blood, it was less significant than in children of the second and third groups $(\mathrm{P} 2,3<0.05)$. But it is worth noting that this difference was not between the groups of the second and third children with IM (P4>0.05).

In children of the studied groups, by the period of reconvalescence, a decrease in the levels of IL-1 $\beta, T N F \alpha$ is noted, more significant in children of the second and third groups, in which there is no mathematical difference in the levels of the indicated interleukins in the blood compared with healthy children $(\mathrm{P} 2,3>0.05)$

At the same time, in children of the first group, the level of pro-inflammatory interleukins by the period of reconvalescence remained at high numbers $(\mathrm{P} 1<0.05)$.

The content of anti-inflammatory interleukin 4 in the blood of children by the period of their recovery exceeded the corresponding indicators of the acute period. However, in the reconvalescence period only in children of the second and third groups there was a significant difference in its content compared with healthy children $(\mathrm{P} 2,3<0.05)$.

It should be noted that in children with a high degree of seeding of streptococcus mucosa of the nasopharynx and oropharynx in the acute period of the disease, a significant decrease in the number of CD3+, CD4+ CD8+ was observed compared with the indicators of children of the second, third and control groups $(\mathrm{P} 1,2,3<0.05)$. The increase in blood CD22+ content was more significant in children of the first group $(\mathrm{P} 1,2,3<0.05)$.

The levels of $\mathrm{CD} 3+, \mathrm{CD} 4+, \mathrm{CD} 8+$ cells were similar to those of the control group (P2,3 $\geq 0.05)$ during the period of early convalescence in children of the second and third groups, which indicated a tendency towards normalization of patients' cellular immunity. This did not occur in children with a high degree of seeding with streptococcus in the nasopharynx. In children of the first group, the content of $\mathrm{CD} 3+, \mathrm{CD} 4+, \mathrm{CD} 8+$ increased during the period of IM convalescence compared with the acute period, but was significantly lower $(\mathrm{P} 1<0.05)$ compared with the control group. As in the acute period, during the period of IM convalescence in children of the first group, we found signs of a deficiency of the cellular immune response, which must be taken into account in the early stages of recovery.

$\mathrm{CD} 22+$ levels in all observation groups decreased by the convalescence period, but remained high compared with the control group (P1,2,3<0.05).

Conclusions. 1 . The microbial flora of the mucous membrane of the nasopharynx determines the formation of the immune response of patients with infectious mononucleosis and, as a result, the symptoms of the disease. Different representatives of the mucobal flora have different effects on the immune response of patients. Streptococcus in mono or in mix forms of infection is most significant.

2. All children showed an increase in the content of IL-1 and TNF- $\alpha$ and a tendency to increase IL-4 in the acute period of IM. The most pronounced changes in the content of proinflammatory interleukins and the least significant anti-inflammatory are observed in children with the presence on the mucous membrane of the nasopharyngeal zone of streptococcus. These changes depend on the degree of seeding of the mucous membrane of streptococcus. In the future, as the clinical manifestations of the disease disappeared, interleukins tended to recover. Less pronounced in cases of the presence of streptococcus in high concentrations in patients.

3. Children who have streptococcus on the mucosa of the nasopharynx and oropharynx have signs of cellular immunodeficiency, which manifests itself as a decrease in the relative content of CD3 ,$+ \mathrm{CD} 4+, \mathrm{CD} 8+$ lymphocytes. The severity of immunodeficiency depends on the degree of seeding of streptococcus of the nasopharynx. In children with a different microflora, only a tendency to the formation of deficiency of immune cells. In the dynamics of the disease, T cell immunity is gradually restored, the most significant in patients without streptococcus.

4. The results of the study can serve as an additional criterion for diagnosing the clinical course of infectious mononucleosis in children, improving treatment and medical rehabilitation of convalescents. 


\section{REFERENCES}

1. Abbott RJ, Quinn LL, Leese AM, Scholes HM, Pachnio A, Rickinson AB. CD8+ T cell responses to lytic EBV infection: late antigen specificities as subdominant components of the total response. J Immunol.2013;191:5398-5409. doi: 10.4049/jimmunol.1301629.

2. Ali AS, Al-Shraim M, Al-Hakami AM, Jones IM. Epstein- Barr Virus: Clinical and Epidemiological Revisits and Genetic Basis of Oncogenesis. Open Virol J. 2015 Nov 3. 9:7-28. [Medline].

3. Bobruk S. V. The degree of indicators level violation of local immunity in children with infectious mononucleosis. Journal of Education, Health and Sport 2017. №3. C. 576-585

4. Cunha BA, Petelin A, George S. Fever of unknown origin (FUO) in an elderly adult due to Epstein-Barr virus (EBV) presenting as "typhoidal mononucleosis," mimicking a lymphoma.Heart Lung. 2013 Jan-Feb. 42(1):79-81. [Medline].

5. Engelmann I, Nasser H, Belmiloudi S, et al. Clinically severe Epstein-Barr virus encephalitis with mild cerebrospinal fluid abnormalities in an immunocompetent adolescent: a case report. Diagn Microbiol Infect Dis. 2013 Jun. 76(2):232-4. [Medline].

6. Rickinson AB, Fox CP. Epstein-barr virus and infectious mononucleosis: what students can teach us. $J$ Infect Dis. 2013 Jan. 207(1):6-8. [Medline].

7. Rostgaard K, Wohlfahrt J, Hjalgrim H. A genetic basis for infectious mononucleosis: evidence from a family study of hospitalized cases in Denmark. Clin Infect Dis. 2014 Jun. 58(12):1684-9. [Medline].

8. Tso K.K., Yip K.Y., Mak C.K., Chung G.T., Lee S.D., Cheung S.T., To K.F., Lo K.W. Complete genomic sequence of Epstein-Barr virus in nasopharyngeal carcinoma cell line C666-1. Infect. Agent. Cancer.2013;8(1):29. doi: 10.1186/1750-9378-8-29. 